\title{
RITUAL INNOVATION IN NUMBERS 18?
}

\author{
Esias E. Meyer \\ University of Pretoria $^{1}$
}

\begin{abstract}
The paper engages with Numbers 18 in the light of the recent debate on ritual innovation. The focus is especially on verses 8-20 and the 'portion' of the priests, or more specifically the Aaronides. The intertextual links between Numbers 18 and other texts in Leviticus are first explored, including texts referring to the firstborn and the ban in Leviticus 27, but also Leviticus 3 and possible links with the peace offering. The article then seeks to find clarity on the diachronic relation between these different texts, before venturing into the debate on ritual innovation. Eventually the article also explores the obvious interests of the priests and how ritualised texts are used in the service of economic innovation.
\end{abstract}

Key Words: Ritual Innovation (Rituele innovasie); Numbers (Numeri); First born (Eersgeborene); Cult (Kultus); Sacrifice (Offer)

\section{Introduction}

In the introduction to a book on ritual innovation written in 2016, Nathan MacDonald writes: ${ }^{2}$

At first blush 'ritual innovation' would appear to be an oxymoron. What is ritual, if not a stereotyped behaviour that has to be practised consistently in order to be effective?

In the rest of that essay MacDonald makes the point that some biblical critics have somehow been resistant to the idea that rituals can change or can even be invented, but that ritual theorists such as Catherine Bell and Ronald Grimes insist that those of us who think that ritual innovation is 'counter-intuitive' are simply wrong. This article is interested in how

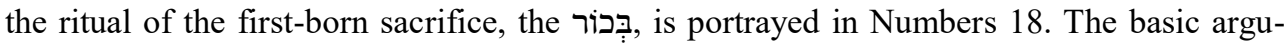
ment is that what we have here is clearly a case of ritual innovation; more specifically, it is a case of what Olyan would call "ritual innovation for profit." 3 Olyan distinguished two kinds of ritual innovation for profit, namely "innovation through the usurpation of another party's ritual privileges" and "innovation by means of the creative manipulation of established rites". I will try to show that what we have here in Numbers 18 is somehow a combination of both kinds of ritual innovation described by Olyan.

The article will focus on two important 'rituals' in Numbers 18, namely the חֶר and the בְּכוֹר , and will look especially at why they are mentioned in such close proximity. It should also become clear that Numbers 18 alludes to several earlier texts from Exodus and Leviticus - and in this case 'earlier' implies both canonically and diachronically. We will also look at Deuteronomy 15, which in my view is also an older text than Numbers 18, although some scholars would disagree with this observation. We do not need to go into the 
debate on what a ritual is exactly, nor address the problem that what we as Old Testament scholars have is actually not rituals, but texts. ${ }^{4}$

Numbers 18 follows after the complex narrative of Numbers 16-17, where the leadership of both Moses and Aaron is challenged. Challengers include Dathan and Abiram from the tribe of Reuben, who "accuse Moses of abusing power in general", and Korah from the tribe of Levi, who accuses "Moses and Aaron of abusing priestly power through their hoarding of holiness." This story of Korah is actually one of those identified by Olyan as being about the usurpation of the privileges of another party. ${ }^{6}$

Most commentaries divide Numbers 18 into at least three parts. Verses 1-7 provide some basic ground rules for the different roles played by priests and Levites. We will focus on the second part, namely verses 8 to 20, which is about priestly compensation, while verses 21-31 are about compensation for Levites. Scholars disagree on where to put verse 20: some see it as the concluding frame of verses 8 to 20 and others as the beginning of the last section. ${ }^{7}$ The focus of this article is on the middle part.

There are quite a few obvious links with, or allusions to, certain chapters from Leviticus which have already been pointed out by many scholars. Chapters 10 and 27 of Leviticus immediately stand out. With Leviticus 10 the most obvious link is the fact that in Numbers 18 Aaron is addressed directly by YHWH in verses 1, 8 and 20. The only other time that this has happened in the preceding chapters is in Leviticus 10:8. In Leviticus 10 Aaron receives certain instructions from YHWH, including verse 10, which commands priests to distinguish between clean and unclean, and between holy and profane. Thus one clear commonality between the two chapters (Lev. 10 and Num. 18) is that in both Aaron gets the undivided attention of YHWH. In Leviticus 10 he receives this attention after paying quite a high price, namely the death of his two firstborn sons. In Numbers 18 other Israelites, such as Korah, pay a price for their own mistakes in the preceding two chapters, their mistake being to challenge the authority of Moses and Aaron. For scholars who engage with diachronic or redactional-critical issues, chapters 10 and 27 of Leviticus are usually regarded as the latest two chapters added to that book, with Christophe Nihan probably offering the best example for this argument. ${ }^{8}$

Apart from this attention that Aaron receives from YHWH, there are many other allusions to texts in Leviticus at which we will look in a moment. I will first look at intertextual links between Numbers 18 and Leviticus 27, and then spread the net wider to include other texts from Leviticus, especially those from Leviticus 1-7 and also the different בִּכוֹר texts from the books of Exodus and Deuteronomy. Apart from the will also look at another practice, namely the חִּר focus especially on verses 14 to 17 . With regard to the preceding verses (vv. 8-13) scholars

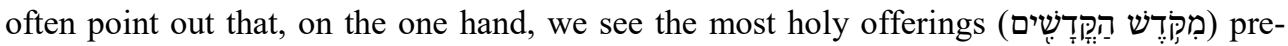
sented in verses 8-10. ${ }^{9}$ These are the מְנָחָה found in Leviticus 2 and 4-7. These offerings may only be eaten by male priests in the "most sacred precincts". 10

On the other hand, from verse 11 onwards we find the lesser offerings, which may be eaten by everyone who is clean in the house of the priest (or literally the addressee, which 
in this case is Aaron). This second group includes first fruits of grain, wine and oil, as well

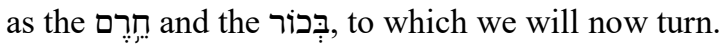

\section{The חִרִֶ}

Numbers 18:14 refers to 'every חֶ? Numbers, at least not as a noun. ${ }^{11}$ As Brekelmans pointed out a long time ago, apart from the Numeruswechsel in Numbers 18:14, the latter verse is a carbon copy of Ezekiel 44:29b, where incidentally we also find the three offerings just described in verse 9 as "most holy". 12

\begin{tabular}{|c|c|}
\hline Ezekiel 44:29 (BHS) & Numbers 18:14 (NRSV) \\
\hline 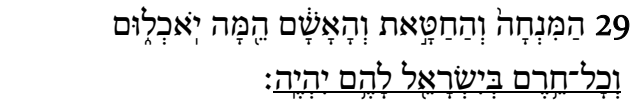 & 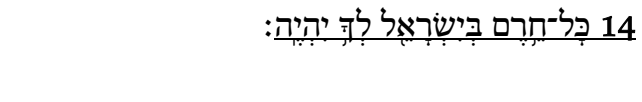 \\
\hline
\end{tabular}

The most important questions with regard to verse 14 are: why mention the חִ̣ and what

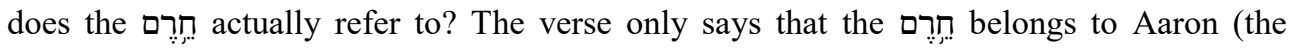
addressee), but gives little information on what exactly a חֶ, is, or what kinds of things could become חֶר? In order to answer the second question (what does it refer to?), many scholars would immediately mention Leviticus 27:28-29. Thus Gray defines the חִִ as something that "appears to mean anything so dedicated to Yahweh that it could not be redeemed." "Leviticus 27:28 mentions that nothing that a person "devoted to destruction" may be sold or redeemed and verse 29 adds specifically that any human who was devoted to destruction may not be redeemed, but must be killed. ${ }^{14}$ Similar to Gray, the more recently published work by Schmidt posits that חִ̣ refers to something "das in besonders feierlicher Weise Jahwe übereignet wurde" and then also refers to Leviticus 27:28. ${ }^{15}$ In the book of Leviticus חִ חִ is found only in chapter 27. Apart from the already mentioned verses

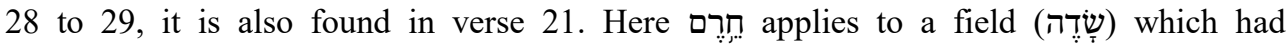
previously been consecrated (v. 19) and ended up being released in the Jubilee, when it becomes a "field of חִ", which is followed by the phrase "for the priest it shall be his possession". It seems that there is a fair amount of overlap between חִִ̣ in Numbers 18:14, where every חִ חרֶם now becomes the possession of the addressee (in this case Aaron), and Leviticus 27:21, where חִ חִ implies something which "for the priest it will be a possession"

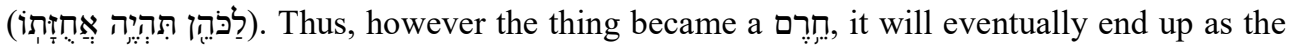
possession of the priest, at least that is the case in Numbers 18:14 and Leviticus 27:21. In both these texts חִֶרִ seems to refer to something becoming the possession of the priest. That is not so clear in verses 28 and 29 (of Lev. 27), where חִ in is actually described as most holy and belonging to YHWH. We could presume that belonging to YHWH means the same as belonging to a priest, but that is not spelled out in verses 28 and 29 as it is in 27:21 and Numbers 18:14.

The meaning of חִ̣ in itself is a much larger debate, with some scholars distinguishing

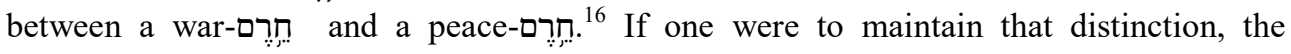


question is where Numbers 18:14 would fit in. Should one read it in the context of Leviticus 27, which most scholars regard as an example of the peace-חרֶ? Or should one read it with texts such as Joshua 6-7 and Deuteronomy 7:28 and 13:18, where the status of חרֶ is the result of war? ${ }^{17}$ In the light of the previously mentioned links with Leviticus 27, I would rather argue for the former. ${ }^{18}$

Another important question with regard to the meaning of חֶ? is whether there is some semantic overlap between חקרִם and a sacrifice. There are obviously at least two schools of thought on this question. Scholars such as Stern and Nelson deny any similarity between a חִ מִר and a sacrifice, while others such as Niditch, Tatlock and even Weinfeld and Milgrom argue that there is some overlap. ${ }^{19}$ I tend to side with the latter group. In Dozeman's latest commentary on the book of Joshua he first provides a useful table of the occurrences of the חִ חִרִ distinguishing between cultic use and war use. ${ }^{20}$ In this case he thus replaces the

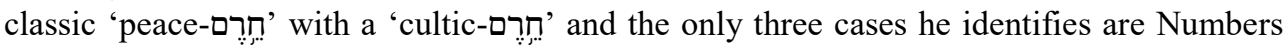
18:14, Leviticus 27:28, 29 and Ezekiel 44:29. He then argues: ${ }^{21}$

The $\mathrm{P}$ literature provides a different interpretation of the ban as sacrifice that is undertaken independently of war, which is also evident in Ezek 44. Leviticus 27 is the primary teaching on this view of the ban, where the noun herem occurs five times to characterise a gift that is given to the Deity in a vow.

I would thus presume with Dozeman that the thing called חִ in Numbers 18 is a kind of a sacrifice similar to that in Ezekiel 44:29 and Leviticus 27:28 and 29, something that might have been given in a vow.

We saw above that 'most holy' was used to refer to the offerings mentioned in verses 810 of Numbers 18 and that most scholars think that what comes after verse 11 onwards is of a lesser degree of holiness. One fascinating difference between Numbers 18:14 and

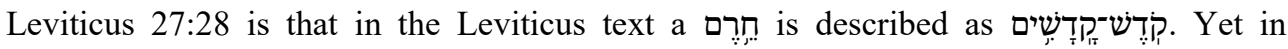

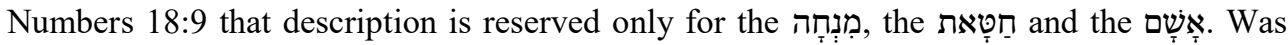
the חֶר thus downgraded in Numbers 18? Milgrom, in his commentary on Leviticus, finds a way of explaining the discrepancy: ${ }^{22}$

Is there, then, a contradiction between Leviticus and Numbers? Not at all. Regarding food, herem is of lesser sanctity and is eligible to be eaten by a priest's family (Num. 18); regarding its irredeemability, it is most sacred (Lev. 27), in contrast to an impure votive animal (vv. 11-13), a consecrated house or field (vv. 14-25), and an impure firstling (v. 27).

Thus for Milgrom there seem to be two categories, one when food is at stake and one when the possibility of redeeming something appears. I am not sure that I find these different categories convincing, since one does not find these kinds of distinctions with other sacri-

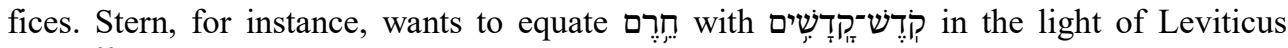
27:28. ${ }^{23}$ He also uses Ezekiel 44:29, where the three most holy sacrifices are mentioned along with the חֶר. Add to that the fact that, as Dozeman reminds us, most definitions provided by scholars for חִ include descriptions like 'to separate' or 'to set aside', which sounds a lot like most definitions provided for 'holiness', 24 and the occurrence of חֶרֶם in 
verse 14 becomes very perplexing. Should חֶֶ? not have been mentioned earlier along with the other three sacrifices, as Ezekiel 44 does? Furthermore, one could ask, what is the

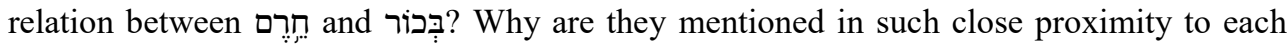
other? Is it simply some kind of alluding device to Leviticus 27, where they are also mentioned in proximity to each other, albeit in a different order? Does the combination of

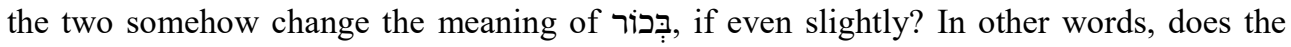

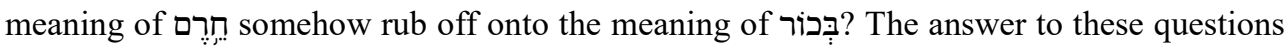
is not that apparent.

For the time being, it is also important to note that the reference to חִרִ in Numbers 18 is much more cryptic than the two references in Leviticus 27. There at least we know that we are talking of a field (v. 21) or an animal or human being (v. 28). In Numbers 18 it is not clear. Yet if Numbers 18 is alluding to Leviticus 27 then those things are presumed.

\section{The}

As we have just argued, it is fascinating to notice that only in Numbers 18 and Leviticus 27

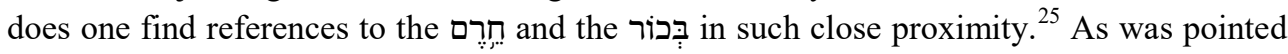

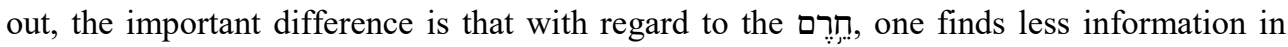
Numbers 18 than in Leviticus 27, but with the בִּכוֹ it it is the other way around. With regard to Leviticus, the term בִּּוֹר is only found once in 27:26, where it refers to an animal which may not be consecrated (Hiphil of קדש: ThWH, since it already belongs to him. ${ }^{26}$ There

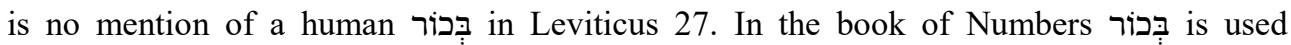
frequently, 25 times to be exact. ${ }^{27}$ Many of these occurrences are from the genealogies, often referring to the oldest male humans, ${ }^{28}$ or animals. ${ }^{29}$ In some cases it also refers to the Levites who are to take the place of an Israelite firstborn. ${ }^{30}$ This, I suppose, raises the question of why YHWH would need a בְּכוֹ sacrifice in Numbers 18, if he already has the

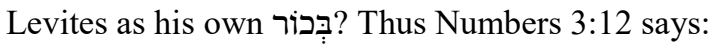

\begin{tabular}{|c|c|}
\hline Numbers 3:12 (BHS) & Numbers 3:12 (NRSV) \\
\hline 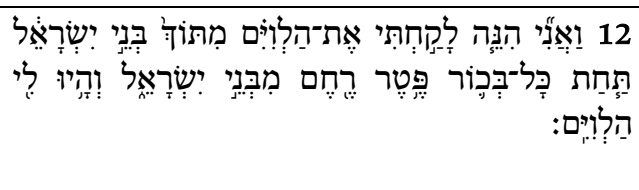 & $\begin{array}{l}12 \text { I hereby accept the Levites from among } \\
\text { the Israelites as substitutes for all the } \\
\text { firstborn that open the womb among the } \\
\text { Israelites. The Levites shall be mine, }\end{array}$ \\
\hline
\end{tabular}

Achenbach, inspired by Budd, offers the classic diachronic answer by arguing that Numbers 3 was written after Numbers 18 as part of his later theocratic layers. ${ }^{31}$ One important difference is that whereas the Levites are always dedicated to YHWH, the Numbers 18 is dedicated to the priests, even if it is via YHWH. It is also important to distinguish between cases where the firstborn simply refers to the firstborn children or animals, and those cases where some kind of sacrifice seem to be the order of the day. Or, to put it differently, cases where it is clear that 'to be sacrificed' or 'ritually killed' is what 
will happen to the firstborn. The latter description fits most of the examples in Numbers 18:15-17:

\begin{tabular}{|c|c|}
\hline Numbers 18:15-17 (BHS) & Numbers 18:15-17 (NRSV) \\
\hline 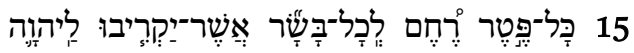 & 15 The first issue of the womb of all \\
\hline 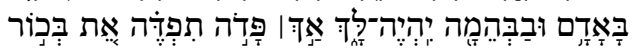 & creatures, human and animal, which is \\
\hline 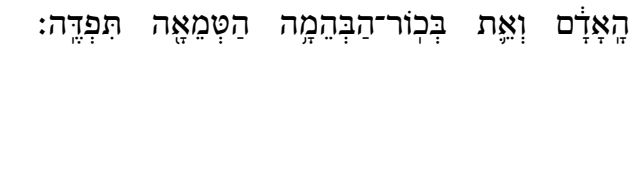 & $\begin{array}{l}\text { offered to the LORD, shall be yours; but the } \\
\text { firstborn of human beings you shall redeem, } \\
\text { and the firstborn of unclean animals you } \\
\text { shall redeem. }\end{array}$ \\
\hline 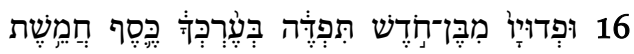 & 16 Their redemption price, reckoned from \\
\hline 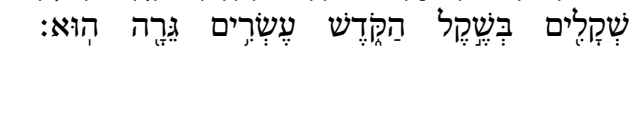 & $\begin{array}{l}\text { one month of age, you shall fix at five } \\
\text { shekels of silver, according to the shekel of } \\
\text { the sanctuary (that is, twenty gerahs). }\end{array}$ \\
\hline 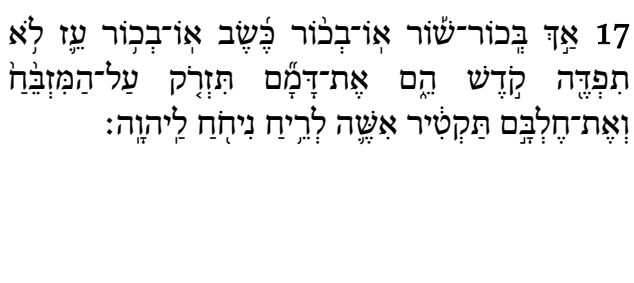 & $\begin{array}{l}17 \text { But the firstborn of a cow, or the } \\
\text { firstborn of a sheep, or the firstborn of a } \\
\text { goat, you shall not redeem; they are holy. } \\
\text { You shall dash their blood on the altar, and } \\
\text { shall turn their fat into smoke as an offering } \\
\text { by fire for a pleasing odor to the LORD; }\end{array}$ \\
\hline
\end{tabular}

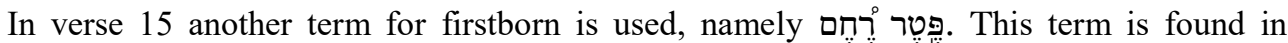

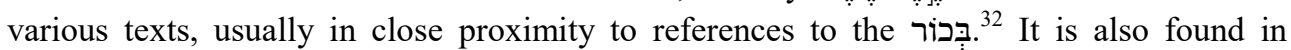
Numbers 3:12, where we had the idea of the Levites replacing the firstborn for the first time. One exception would be the notorious Ezekiel 20:26, where the term

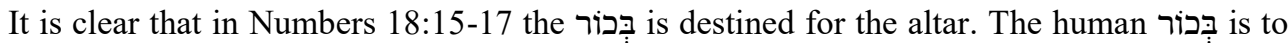
be redeemed (פדה) and the same goes for unclean animals. The verb פדה is found here only in these verses in the book of Numbers and also in Leviticus 27:27 and 29, where it refers

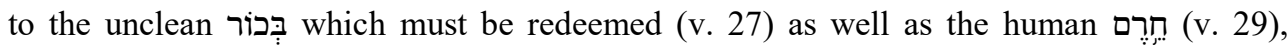
which may not be redeemed and must be killed. The verb also features in some of the Exodus texts we will discuss in a moment. As said before, there is no mention of the human

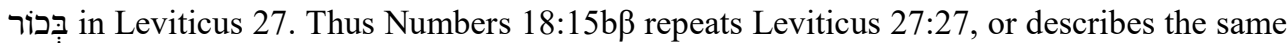
outcome: every unclean בְִֹּּּ animal must be redeemed.

\begin{tabular}{|c|c|}
\hline Leviticus 27:27 & Numbers 18:15 \\
\hline 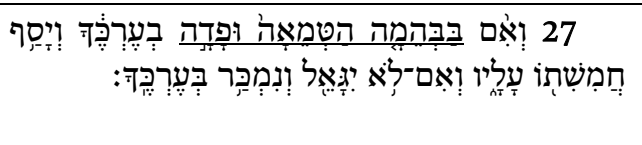 & 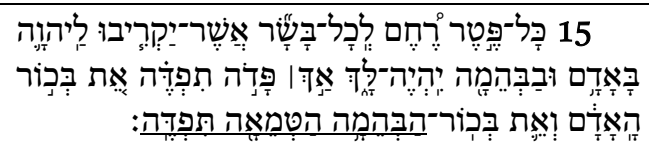 \\
\hline
\end{tabular}


In both cases the בִּכוֹר of the unclean animal must be redeemed, but the prices are slightly different as verse 16 shows. In Numbers 18:16 the price is set at five shekels. In Leviticus

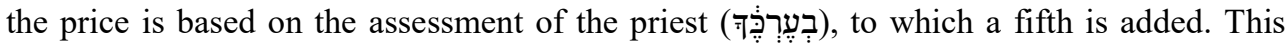
assessment is a set amount and the five shekels in Numbers 18:16 is the equivalent of a male of between one month and five years, according to Leviticus 27:8. These specific details about money are probably why Noth describes Numbers 18:16 and other texts such as Leviticus 27 as examples "of the progressive 'commercialisation' of the character of the cult." ${ }^{, 33}$ Numbers 18:16 also specifies the value of a shekel at twenty גרירָה "This specification occurs only five times in the Hebrew Bible, of which one is Leviticus 27:25. ${ }^{34}$ One should also add that a few scholars would argue that verse 16 was added later and the text reads much more smoothly as only verses 15 and $17 .{ }^{35}$ Furthermore, verse 16 seems to refer to humans, whereas Leviticus 27:26 only refers to unclean animals.

Thus it should be clear that Numbers 18:16 also resonates with different verses from Leviticus 27. The expression ' this text and is found only in Priestly and post-Priestly texts between Exodus, Leviticus and Numbers, with a high concentration in Numbers 7, where it is used to describe the value of the offerings brought by many tribal leaders. ${ }^{36}$ In Leviticus 27:3 the term is used at the beginning of prescriptions discussing the value of human beings dedicated in vows. In 27:25 it concludes a longer section on 'assessment' reiterating that the only value to be used is the shekel of the sanctuary.

Numbers 18:17 makes it very clear that the firstborn of cattle, sheep and goats may not be redeemed and their blood must be dashed on the altar and their fat must be burned as "pleasing odour to the Lord". This language is vintage Leviticus. Usually when blood is splashed, this is done over the altar, ${ }^{37}$ but in one instance the people ${ }^{38}$ could also be the recipients of the blood. The splashing of blood on the altar is mostly referred to in the book

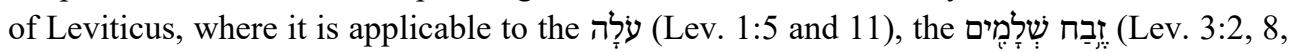
13 and 7:14) and the אָָָׁ (Lev. 7:2). The reference to the 'pleasing odour' is associated with these sacrifices, but also the מְנְחָה (Lev. 2:2) and the 4:31). Thus suddenly in Numbers 18 the בְּכּוֹ seems to be on par with all five offerings in Leviticus 1-7.

Another striking feature of the ritual of the בִּּ in Numbers 18 is the fact that the ritual is described in much more detail than in Leviticus 27, or any of the famous in Exodus. Part of this detail overlaps to a large extent with the description of the Leviticus 3. In Numbers 18:17 the fat is to be burned and the same goes for the fat in Leviticus 3:3-5, although other parts are added there such as the kidneys and the appendage of the liver in Leviticus 3. Also in Leviticus 3 the description of the fat is much more elaborate. 


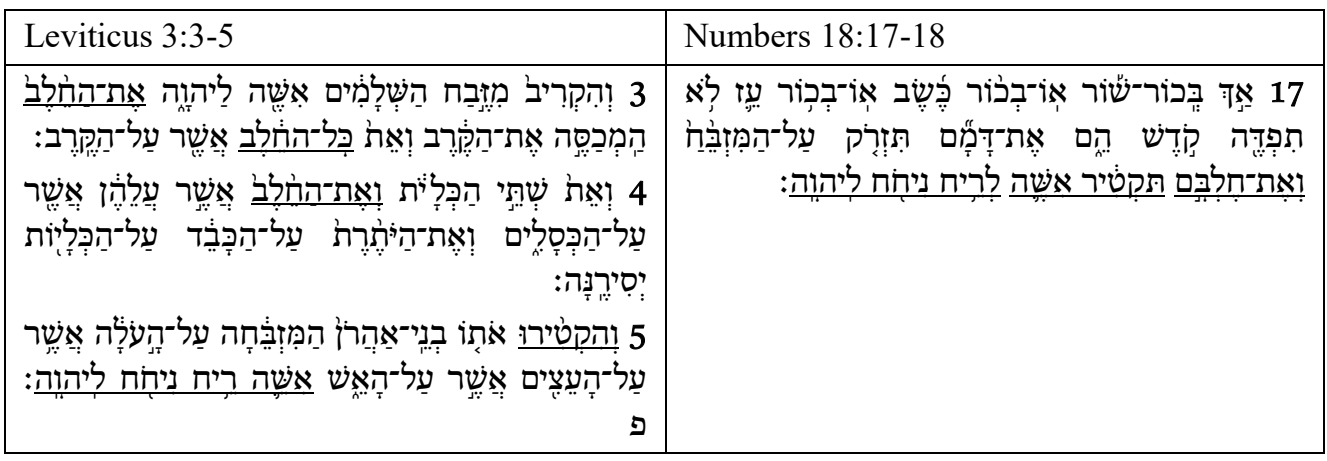

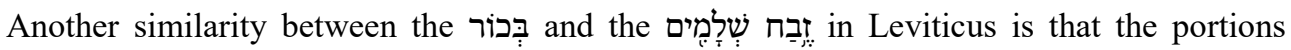
identified in verse 28 are the same as those reserved for the priest in Leviticus 7:34:

\begin{tabular}{|c|c|}
\hline Leviticus 7:34 & Numbers 18:18 \\
\hline 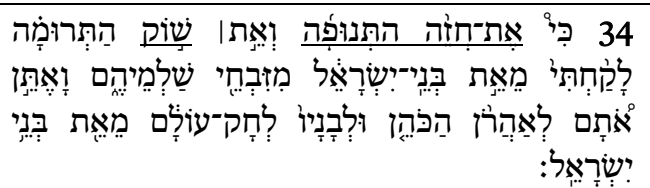 & 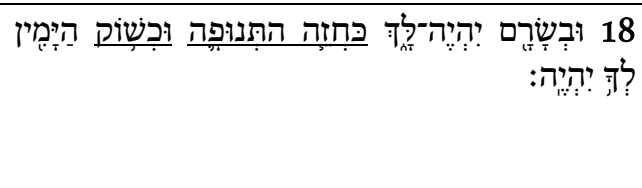 \\
\hline
\end{tabular}

It is strange that these portions are specified in Numbers 18:18, since the priests now get everything in any case. The preposition Ðִ is clearly used to compare. "All their flesh" as it is with the breast and as with the leg now belongs to 'you', 'you' being Aaron the addressee. Levine explains the problem as follows: ${ }^{39}$

Although the law here is clearly modeled on the law of the šelammim offering, as its formulation indicates, it applies the provisions of that law to another category. The law states that all of the unburned flesh of firstlings is of a status comparable with the specific section of the šelāmîm, the breast and thigh, which go to the priests.

It is not clear what is meant by 'another category'. One should also add that the is always described as voluntary, yet the impression given by Numbers 18 and all the texts that follow is that it is very much compulsory. ${ }^{40}$

What I have tried to show up to this point is that Numbers 18:9-20 often alludes to different chapters from Leviticus. We have chapter 10 with Aaron, being addressed, but

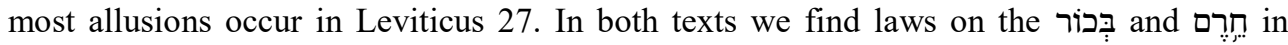
close proximity. The reference to the latter is very terse in Numbers 18, but much more elaborate in Leviticus 27, yet with the is is the other way around. Apart from these links, what is also clear is that the way in which the בִּכֹ is described in Leviticus 27 also

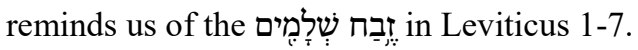

We first need to take a step back and have a brief look at the four in the book of Exodus. Since I presume they are all older than this chapter from the book of Numbers, I 
will not go into much detail with regard to their diachronic relationship to each other. Any discussion of these texts could take us to the larger debate on human sacrifice in the Hebrew Bible, a debate of which we will try to stay clear. ${ }^{41}$ The four texts are Exodus 13:2, 12-13, 22:29 and 34:19-20. In all four texts we find reference to the wiּ which belongs to YHWH, although different ways are used to express this belonging to YHWH. In each case both humans and animals are mentioned and in two cases (Ex. 13:12-13 and 34:19-20) humans are redeemed. In Exodus 13:2 the verb קדש (Pi'el) is used to describe the dedication of the בְּכוֹ YHWH. Later in the same chapter in verses 12-13 the first to open the womb is to be set apart (Hiphil of עבר ברר (He same verb used in Ezekiel 20:26. Verse 13

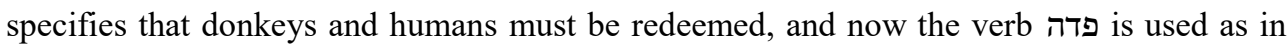
Numbers 18. Exodus 22:29 demands that the בִּכוֹר (נתן) of 'your sons' must be given to YHWH. Lastly, in Exodus 34:19-20 we find a similar command to that of 13:12-13. We find reference to "the one who opens the womb" who belongs to YHWH. This 'belonging' is expressed by means of a nominal sentence with לִי in the predicate. In verse 34:20 we hear once again that the donkey and the firstborn son are to be redeemed (again פדה). In none of these verses do we find any additional specifics about how the ritual is to be executed. In Exodus 13:14 we hear that when children were to ask about the meaning of the בְּכ , then the answer will be a retelling of what YHWH did to the firstborn in Egypt and then the parent will add: ${ }^{42}$

\begin{tabular}{|c|c|}
\hline Exodus 13:15b (BHS) & Exodus 13:15b (NRSV) \\
\hline 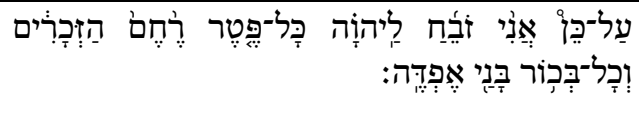 & $\begin{array}{l}\text { Therefore I sacrifice to the LORD every } \\
\text { male that first opens the womb, but every } \\
\text { firstborn of my sons I redeem.' }\end{array}$ \\
\hline
\end{tabular}

If there was any doubt that we were talking of a sacrifice, then this makes it clear that a sacrifice is the order of the day. It should also be clear that there is no hint here that these sacrifices will be destined for the priests. But then there is not much clarity on how these sacrifices will be performed, who will eat them, if anyone, and what will happen to the blood.

One should also mention one other text, namely Deuteronomy 15:19-23. This text has many noteworthy features. As in Exodus 13:2 the verb קדש (Hiphil here, but Pi'el in Exodus 13) is used to describe the dedication of the firstborn. One also finds the verb זבח in verse 21 , making it clear that this is a sacrifice. What is different, though, is that here the firstborn is specifically described as 'male', something which was absent in all the texts from Exodus as well as Leviticus 27 and Numbers 18. Yet the main difference between this text and the one in Numbers is what Finsterbusch has called the 'farmer-friendly' character of Deuteronomy 15, over again the 'priest-friendly' character of Numbers $18 .{ }^{43}$ In Deuteronomy 15 the farmer and his family eat the but as as we know, in Numbers 18 the eating of the בִּכוֹר is reserved for the priests. The same ritual is described to favour two vastly different groups. In Deuteronomy 15 we also read what happens to the blood, but this is poured out like water onto the ground and is not dashed onto the altar as in Numbers 18 . 
Yet both Numbers 18 and Deuteronomy 15 are different from all the other texts simply because they at least provide us with more detail of who eats what, or who stands to gain most from this ritual.

Yet even if one ignores Deuteronomy, the movement between the discussed texts from

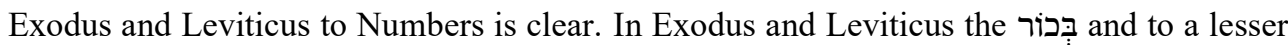

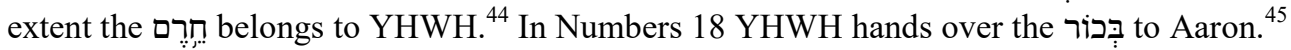
If there had been any doubt about what "belonging to YHWH" meant before in Exodus and Leviticus, that doubt has now been removed.

\section{Conclusion}

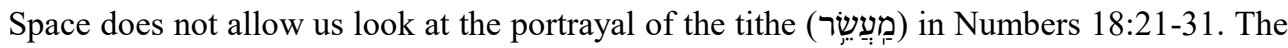
tithe also features after the חֶר in Leviticus 27, where it also belongs to YHWH. It is absent in Exodus, but it is found in Deuteronomy 14:22-27, where the farmer can eat it. ${ }^{46}$ The farmer is encouraged in verse 27 not to neglect the poor Levites, but still he and his family may eat the whole tithe. Yet in Numbers 18:21-31 YHWH hands over the tithe to the Levites, although they need to hand over $10 \%$ of that to Aaron. ${ }^{47}$ That Deuteronomy is pro-farmer, as Finsterbusch pointed out, is very clear. That Numbers 18 is pro-Aaron is also very clear. Olson reminds us to read these texts with a "healthy hermeneutic of suspicion":

Readers infected with a healthy dose of a hermeneutics of suspicion may look at this material rather cynically. They may conclude that these stories are simply pro-Aaronic propaganda pieces designed to ensure unquestionable loyalty and support to the one surviving priestly group who had the final word in giving these stories their present shape.

This article, obviously, espouses such a hermeneutics of suspicion, but the aim is more to show how the 'loyalty' and 'support' mentioned by Olson has been co-opted. We have tried to show how a ritual such as the בִּכּוֹ is reinvented to serve the interests of the priests. We tried to show how the text of Numbers 18 echoes other texts such as Leviticus 10 and 27. As in Leviticus 27 בִּכוֹר 2 is mentioned in close proximity to the but in different

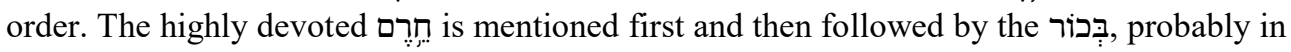

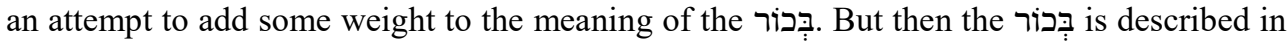

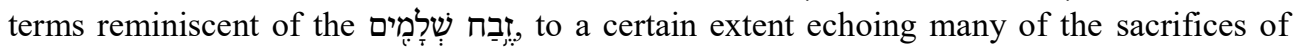
Leviticus 1-7. One might get the impression that it is written into Leviticus 1-7 retroactively, since it becomes a similar sacrifice where blood is dashed and where a 'pleasing odour' lingers. Yet when compared to the four בִּכּוֹ texts in Exodus, the most important

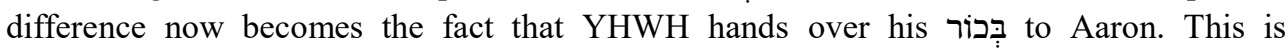
something which was probably implied in those texts, but is made explicit now. Olyan's concept of "creative manipulation" seems appropriate.

One wonders what remains for YHWH, now that he has handed over the בִּכוֹ Aaron? Well, according to Numbers 18 , there is still that lingering 'pleasing odour' which is also what Leviticus 1-7 provides, a kind of aromatherapy? 


\section{BIBLIOGRAPHY}

Achenbach, Reinhard. Die Vollendung der Tora. Studien zur Redaktionsgeschichte des Numeribuches im Kontext von Hexateuch and Pentateuch. Beihefte zur Zeitschrift für Altorientalische und biblische Rechtsgeschichte. Wiesbaden: Harrassowitz, 2003.

Ashley, Timothy R. The Book of Numbers. The New International Commentary on the Old Testament. Grand Rapids: Michigan, 1993.

Bosman, Hendrik. "'What does this mean?' The Exodus as answer within the inner-biblical discussion of Exod. 13,14 with Deut. 6,20 and Josh. 4,21." Pages 31-44 in A Pillar of Cloud to Guide. Text-critical, Redactional, and Linguistic Perspectives on the Old Testament in Honour of Marc Vervenne. Bibliotheca Ephemeridum Theologicarum Lovaniensium 269. Edited by Hans Ausloos and Bénédicte Lemmelijn; Leuven: Peters, 2014.

Brekelmans, C.H.W. De Herem in het Oude Testament. Nijmegen: Centrale Drukkerij, 1959.

Budd, Phillip J. Numbers. WBC 5. Dallas: Word, 1998.

Dozeman, Thomas B. "The Book of Numbers." Pages 1-268 in The New Interpreter's Bible. Volume II. Edited by Leander E. Keck. Nashville: Abingdon, 1998.

Dozeman, Thomas B. The Pentateuch. Introducing the Torah. Minneapolis: Fortress Press, 2017.

Dozeman, Thomas B. Joshua 1-12. A New Translation with Introduction and Commentary. The Anchor Yale Bible. New Haven: Yale University Press, 2008.

Finsterbusch, Karin. "The First-Born between Sacrifice and Redemption in the Hebrew Bible" Pages 87-108 in Human Sacrifice in Jewish and Christian Tradition. Edited by Karin Finsterbusch, Armin Lange and K.F. Deithard Römheld. Leiden: Brill, 2007.

Frevel, Christian. "Practicing Ritual in a Textual World: Ritual and Innovation in the Book of Numbers." Pages 129-150 in Ritual Innovation in the Hebrew Bible and Early Judaism. Beihefte zur Zeitschrift für die alttestamentliche Wissenschaft 468. Edited by Nathan MacDonald. Berlin: De Gruyter, 2016.

Gerstenberger, Erhard S. Das 3. Buch Mose. Leviticus. Altes Testament Deutsch 6. Göttingen: Vandenhoeck \& Ruprecht, 1993.

Gispen, W.H. Het boek Numeri. Eerste Deel. Commentaar op het Oude Testament. Kampen: N.V. Uitgeversmaatschappij J.H. Kok, 1959.

Gorman, Frank H. "Sacrifices and Offerings." Pages 20-32 in The New Interpreters Dictionary of the Bible - S-Z Volume 5. Edited by Katharine D. Sakenfeld. Nashville: Abingdon Press, 2009.

Gray, George B. A Critical and Exegetical Commentary on Numbers. International Critical Commentary. Edinburgh: T\&T Clark, 1903.

Hattingh, Arend J.K. and Meyer Esias E. “'Devoted to Destruction'. A Case of Human Sacrifice in Leviticus 27?” Journal for Semitics 25/2 (2016):630-657.

Jagersma, H. Numeri. Deel II. De Prediking van het Oude Testament. Nijkerk: Callenbach, 1988. 
Kilchör, Benjamin. Mosetora und Jahwetora: Das Verhältnis von Deuteronomium 12-26 zu Exodus, Levitikus und Numeri. Beihefte zur Zeitschrift für Altorientalische und Biblische Rechtsgeschichte 21. Wiesbaden: Harrassowitz, 2015.

Knierim, Rolf P. \& Coats, George W. Numbers. The Forms of the Old Testament Literature. Volume IV. Grand Rapids: Eerdmans, 2005.

Levine, Baruch A. Numbers 1-20. A New Translation with Introduction and Commentary. The Anchor Yale Bible. New York: Doubleday, 1993. Repr., New Haven: Yale University Press, 2008.

MacDonald, Nathan. "Strange Fire before the Lord: Thinking about Ritual Innovation in the Hebrew Bible and Early Judaism." Pages 1-10 in Ritual Innovation in the Hebrew Bible and Early Judaism. Beihefte zur Zeitschrift für die alttestamentliche Wissenschaft 468. Edited by Nathan MacDonald. Berlin: De Gruyter, 2016.

Milgrom, Jacob. Numbers במדבר. The JPS Torah Commentary. Philadelphia: The Jewish Publication Society, 1990.

Milgrom, Jacob. Leviticus 1-16: A New Translation with Introduction and Commentary. The Anchor Bible, New York: Doubleday, 1991.

Milgrom, Jacob. Leviticus23-27: A New Translation with Introduction and Commentary. The Anchor Yale Bible, New York: Doubleday, 2001. Repr., New Haven: Yale University Press, 2010.

Nelson, R. D. "herem and the Deuteronomic Social Conscience.” Pages 39-54 in Deuteronomy and Deuteronomic Literature. Festschrift C.H.W. Brekelmans. Bibliotheca Ephemeridum Theologicarum Lovaniensium 133. Edited by Marc Vervenne and Johann Lust. Leuven: Peters, 1997.

Niditch, Susan. War in the Hebrew Bible: A Study of the Ethics of Violence. Oxford: Oxford University Press, 1993.

Nihan, Christophe. From Priestly Torah to Pentateuch. Forschungen zum Alten Testament II 25. Tübingen: Mohr Siebeck, 2007.

Noth, Martin. Numbers. A Commentary. Translated by James D. Martin. The Old Testament Library. London: SCM Press, 1968.

Olson, Dennis T. Numbers. Interpretation. Louisville: John Knox Press, 1996.

Olyan, Saul M. "Two Types of Ritual Innovation for Profit.” Pages 11-20 in Ritual Innovation in the Hebrew Bible and Early Judaism. Beihefte zur Zeitschrift für die alttestamentliche Wissenschaft 468. Edited by Nathan MacDonald. Berlin: De Gruyter, 2016.

Otto, Eckart. Deuteronomium 12-34. Erster Teilband: 12,1-23,15. HTK; Freiburg: Herder, 2015.

Schmidt, Ludwig. Das vierte Buch Mose. Numeri. Kapitel 10,11-36,13. ATD 7.2. Göttingen: Vandenhoeck \& Ruprecht, 2004.

Seebass, Horst. Numeri 10, 11-22,1. Biblischer Kommentar Altes Testament 4.2. Neukirchen-Vluyn: Neukirchener, 2003.

Stern, Phillip D. The Biblical HEREM. A Window on Israel's Religious Experience. Atlanta: Scholars Press, 1991.

Stravrakopoulou, Francesca. King Manasseh and Child Sacrifice. Biblical Distortions of Historical Realities. BZAW 338, Berlin: De Gruyter, 2004. 
Tatlock, Jason R. How in Ancient Time They Sacrificed People: Human Immolation in the Eastern Mediterranean Basin with Special Emphasis on Ancient Israel and the Near East. Unpublished $\mathrm{PhD}$ dissertation, University of Michigan, 2006.

Watts, James W. Leviticus 1-10. Volume 5. Historical Commentary on the Old Testament, Leuven: Peeters, 2013.

Weinfeld, Moshe. "The Worship of 'Molech' and of the Queen of Heaven and its Background." Ugarit Forschungen 4 (1972):133-154.

Wright, David P. "Ritual Theory, Ritual Texts, and the Priestly-Holiness Writings of the Pentateuch," Pages 21-34 in Social Theory and the Study of Israelite Religion: Essays in Retrospect and Prospect. Edited by Saul M. Olyan. Atlanta: Society of Biblical Literature, 2012.

\section{Endnotes}

1 This article on Numbers 18 reinterpreting earlier texts in the Pentateuch is presented as an offering (not the firstborn kind fortunately) as acknowledgment of the role that Hendrik Bosman played in stimulating the study of the Pentateuch in South Africa. As an under- and postgraduate student of his, I bear witness to this reality.

2 Nathan MacDonald, "Strange Fire before the Lord: Thinking about Ritual Innovation in the Hebrew Bible and Early Judaism," in Ritual Innovation in the Hebrew Bible and Early Judaism. ed. N. MacDonald (BZAW 468; Berlin: De Gruyter, 2016), 1-10, here p. 1.

3 Saul M. Olyan, "Two Types of Ritual Innovation for Profit," in Ritual Innovation in the Hebrew Bible and Early Judaism. (ed. N. MacDonald; BZAW 468; Berlin: De Gruyter, 2016), 11-20, here p. 11.

4 See especially David P. Wright, "Ritual Theory, Ritual Texts, and the Priestly-Holiness Writings of the Pentateuch," in Social Theory and the Study of Israelite Religion: Essays in Retrospect and Prospect, ed. Saul M. Olyan (Atlanta: Society of Biblical Literature, 2012), 21-34, here pp. 197-199. See also Christian Frevel, "Practicing Ritual in a Textual World: Ritual and Innovation in the Book of Numbers," in Ritual Innovation in the Hebrew Bible and Early Judaism, ed. Nathan MacDonald (BZAW 468; Berlin: De Gruyter, 2016), 129-150, who also reminds us of the fact that we study rituals in a 'textual world'.

5 Thomas B. Dozeman, The Pentateuch. Introducing the Torah (Minneapolis: Fortress Press), 2017.

6 Olyan, "Two Types," 13-14.

7 Commentators who read verse 20 with the third part include: Rolf P. Knierim, \& George W. Coats, Numbers (FOTL IV; Grand Rapids: Eerdmans, 2005), 287; G.W. Gispen, Het boek Leviticus. Eerste Deel (COut; Kampen: J.H. Kok, 1959), 287 and Ludwig Schmidt, Das vierte Buch Mose. Numeri. Kapitel 10, 11-36, 13 (ATD 7.2. Göttingen: Vandenhoeck \& Ruprecht, 2004), 81. Those who think that verse 20 belongs with the second part include: Timothy R. Ashley, The Book of Numbers (NICOT; Grand Rapids: Michigan, 1993): 353; Thomas B. Dozeman, “The Book of Numbers," Pages 1-268 in The New Interpreter's Bible. Volume II (ed. Leander E. Keck; Nashville: Abington, 1998), 1-268, here p. 147; Horst Seebass, Numeri 10, 11-22,1 (BKAT 4.2; Neukirchen-Vluyn: Neukirchener, 2003), 225 and H. Jagersma, Numeri. Deel II (POut; Nijkerk: Callenbach, 1988), 46.

8 Christophe Nihan, From Priestly Torah to Pentateuch (FAT II 25; Tübingen: Mohr Siebeck, 2007), 545-558 and 576-605.

9 See Dozeman, "Book of Numbers", 147

10 Baruch A. Levine, Numbers 1-20. A New Translation with Introduction and Commentary (AB; New York: Doubleday, 1993. Repr., New Haven: Yale University Press, 2008), 445.

11 The verb חרם (Hiphil) occurs twice in Numbers 21:2-3.

12 C.H.W. Brekelmans, De Herem in het Oude Testament (Nijmegen: Centrale Drukkerij, 1959), 66-67.

13 George B. Gray, A critical and exegetical commentary on Numbers (ICC; Edinburgh: T\&T Clark, 1903 ), 229. See also Seebass, Numeri 10, 11-22, 1, 232. 
14 Levine, Numbers 1-20, 447. Levine, for instance, would like to link the חֶר in Numbers 18:14 to Leviticus 27:29, which he then links to Exodus 22:19, where a person is sentenced to death for worshipping other gods. Thus for Levine Numbers 18:14 refers to somebody who forfeited his property when he sacrificed to other gods. This seems like a bit of a stretch, but in the Exodus verse the Hophal of חֶר is used as in Leviticus 27:29. In this interpretation verse 29 is a later addition, which has nothing to do with verse 28 . This idea is rejected by many. See Philip D. Stern, The Biblical HEREM. A Window on Israel's Religious Experience (Atlanta: Scholars Press, 1991), 128-131; Erhard S. Gerstenberger, Das 3. Buch Mose. Leviticus (ATD 6: Göttingen: Vandenhoeck \& Ruprecht, 1993), 407 and Arend J.K. Hattingh and Esias E. Meyer, “Devoted to Destruction'. A Case of Human Sacrifice in Leviticus 27?" Journal for Semitics 25/2 (2016):630-657, here pp. 650-3. For Ashley, The Book of Numbers, 350, the text apparently refers to a war-ם חִ and he does not seem familiar with the usual distinction between a war- and a peace-

Schmidt, Das vierte Buch Mose, 80.

16 See especially Stern, The Biblical HEREM, 125-135, or, Jacob Milgrom, Leviticus23-27: A New Translation with Introduction and Commentary (AB; New York: Doubleday, 2001; repr., New Haven: Yale University Press, 2010), 2391-2392, who acknowledges that both kinds of חֶר could be attested, but disagrees with Stern on the post-exilic development of the peace- חרֶ. Brekelmans, De Herem, 163-170 actually distinguishes

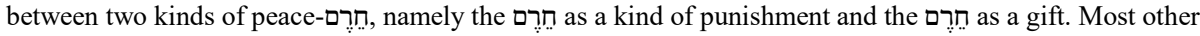
scholars would not make this distinction.

17 See Levine, Numbers 1-20, 436.

18 It is difficult to be certain, though. Thus Martin Noth. Numbers. A Commentary (trans. James D. Martin; OTL; London: SCM Press, 1968), 136, adds 'as if the possibility still existed of a 'holy war' in which the booty was to be put under the 'ban'", and he then adds Leviticus 27:28-29.

19 See Stern, The Biblical HEREM, 173-174 and R.D. Nelson, "herem and the Deuteronomic Social Conscience," in Deuteronomy and Deuteronomic Literature. Festschrift C.H.W. Brekelmans, ed. Marc Vervenne and Johann Lust (BETL 133; Leuven: Peters, 1997), 39-54, here p. 48, who both argue that חֶר has nothing to do with a sacrifice. Scholars who argue that the חֶ can at times be regarded as a kind of sacrifice include Moshe Weinfeld, "The Worship of 'Molech' and of the Queen of Heaven and its Background," Ugarit Forschungen 4 (1972):133-154, here p. 133, who regards it as a kind of 'human sacrifice.' See also Milgrom, Leviticus 23-27, 2420-2421, who responds to Stern, or Jason R. Tatlock, How in Ancient Time They Sacrificed People: Human Immolation in the Eastern Mediterranean Basin with Special Emphasis on Ancient Israel and the Near East. (Unpublished Ph.D. dissertation, University of Michigan, 2006), 173. See Susan Niditch, War in the Hebrew Bible. A Study in the Ethics of Violence (Oxford: Oxford University Press, 1993), 28-55, for an extensive discussion on why she thinks that a חִ is a kind of sacrifice.

Thomas B. Dozeman, Joshua 1-12. A New Translation with Introduction and Commentary (AB; New Haven:Yale University Press, 2008), 55.

Milgrom, Leviticus 23-27, 2394. See also his earlier commentary, Jacob Milgrom, Numbers במדבר. (JPS; Philadelphia: The Jewish Publication Society, 1990), 429.

Stern, The Biblical Herem, 126-127.

The only other place in the Hebrew Bible where the two terms are found in close proximity is 1 Chronicles 2:3-7. בְּכוֹר is found in 2:3, but refers to the firstborn son and has nothing to do with a possible sacrifice. In 2:7 there is mention of Achar, who "transgressed in the matter of the As we will see later, this command seems to be directly opposed to Exodus 13:2 and Deuteronomy 15:19, where the Israelites are indeed commanded to 'consecrate' (קדש Piel in Ex. and Hiphil in Dt.) the firstborn. Yet Leviticus 27:26 uses the Pual of בכר to describe this process of belonging to YHWH. Numbers 1:20, 3:2, 12, 13(x3), 40, 41(x2), 42, 43, 45, 46, 50, 8:16, 17(x2), 18, 18:15(x2), 17(x3), 26:5 and $33: 4$.

Numbers $1: 2,3: 2,13(\mathrm{x} 2), 40,42,43,50 ; 17(\mathrm{x} 2) ; 26: 5$ and $33: 4$.

30 Numbers $3: 12,41,45,47 ; 8: 16$ and 18. In most of these cases the Levites are mentioned as the ones who will take the place of the first born. 
31 Reinhard Achenbach. Die Vollendung der Tora. Studien zur Redaktionsgeschichte des Numeribuches im Kontext von Hexateuch and Pentateuch (BZAR 3; Wiesbaden: Harrassowitz, 2003), 160 and Phillip J. Budd, Numbers (WBC 5; Dallas: Word, 1998), 203.

32 Exodus 13:2, 12(x2), 13, 15, 34:19(x2), Numbers 3:12, 18:15; Ezekiel 20:26 and 2 Chronicles 23:8. In all of these examples, apart from the last two, we also find references to the Noth, Numbers, 136.

34 Exodus 30:13; Leviticus 27:25; Numbers 3:34, 18:16 and Ezekiel 45:12.

35 E.g. Noth, Numbers, 136 and Seebass, Numeri 10, 11-22,1, 232.

36 Exodus 30:13, 24; 38:24, 25, 26; Leviticus 5:15, 27:3, 27:25; Numbers 3:47, 50, 7:13, 19, 25, 31, 37, 43, 49, $55,61,67,73,79,85,86,18: 16$. 'Offerings' in the case of Numbers 7 does not refer to sacrifices, but mostly to silver plates which were donated to the sanctuary. See Achenbach, Vollendung, 161, for a fascinating discussion which has implications for dating this text. For Achenbach it is clear the temple already has its coins, a fact with which the author of Nehemiah 10:33 is not familiar.

37 Exodus 24:6, 29:16, 20; Leviticus 1:5, 11, 3:2, 8, 13, 7:2, 14, 8:19, 24, 9:12, 18, 17:6; Numbers 18:17; 2 Kings 16:13, 15; Ezekiel 43:18; 2 Chronicles 29:22 (x3). In 2 Chronicles 30:16 and 35:11 the altar is not mentioned, but apparently presumed.

Exodus 24:8.

39 Levine, Numbers 1-20, 448.

40 See especially Frank H. Gorman, 'Sacrifices and offerings,' in The New Interpreters Dictionary of the Bible S-Z Volume 5, ed. Katharine D. Sakenfeld (Nashville: Abingdon Press, 2009), 20-32, here p. 24.

41 For a detailed discussion, see Francesca Stravrakopoulou, King Manasseh and Child Sacrifice. Biblical Distortions of Historical Realities (BZAW 338; Berlin: De Gruyter, 2004), 179-191 and Karin Finsterbusch, "The First-Born between Sacrifice and Redemption in the Hebrew Bible," in Human Sacrifice in Jewish and Christian Tradition.(ed. Karin Finsterbusch, Armin Lange and K.F. Deithard Römheld (Leiden: Brill, 2007), 87-108.

42 See Hendrik Bosman, "What does this mean?' The Exodus as answer within the inner-biblical discussion of Exod 13,14 with Deut 6,20 and Josh 4,21," in A Pillar of cloud to guide. Text-critical, Redactional, and Linguistic Perspectives on the Old Testament in Honour of Marc Vervenne. (BETL 269; ed. Hans Ausloos and Bénédicte Lemmelijn; Leuven: Peters, 2014), 31-44, here pp. 32-35. For Bosman the question asked by the children points to a Wisdom influence and he understands 13:1-16 as a "combination of priestly commemoration and scribal instruction."

43 Finsterbusch, "The First-Born," 102.

44 One exception would be Leviticus 27:21 where the field became חֶר and went to the priest after being released in the Jubilee.

45 See the discussion in Benjamin Kilchör, Mosetora und Jahwetora. Das Verhältnis von Deuteronomium 12-26 zu Exodus, Levitikus und Numeri (BZAR 21; Wiesbaden: Harrassowitz Verlag, 2015), 161, where he sums up the laws on the firstborn in three stages. In the Exodus texts the firstborn belongs to YHWH. In Numbers 18 the firstborn is destined for the priesthood. Kilchör's third stage is then Deuteronomy 15, where the firstborn is given to the farmer. This last portrayal of Deuteronomy, from a diachronic perspective, will obviously be disputed by many scholars, myself included. What is clear is that Deuteronomy and Numbers have totally opposing views.

46 Eckart Otto, Deuteronomium 12, 1-23, 15, (HThKAT; Freiburg: Herder; 2016), 1335, actually regards Deuteronomy 14:22-27 and 15:13-23 as a frame around chapter 15 .

47 See Seebass, Numeri 10, 11-22, 1, 220, who regards verses 21-24 as very diplomatic towards the Levites. 